\title{
A simple latex slide test for rheumatoid arthritis using the gamma globulin in the patient's serum
}

\author{
R. BIRD AND R. G. BURR \\ From the Department of Pathology, Royal Northern Hospital, London
}

SYNOPSIS A latex slide test is described which is suitable for handling large numbers of specimens The buffered latex suspension used is easily prepared from stable stock solutions at relatively low cost. It is not necessary to add Cohn fraction II ( $\gamma$ globulin) to the latex reagent. A comparison hai been made with the sheep cell agglutination (Rose-Waaler) test in 508 cases and a $96 \%$ overait agreement obtained. Factors influencing the test have been investigated.

A number of serological tests dependent on the aggregation of latex particles in the presence of Cohn fraction II ( $\gamma$ globulin) by rheumatoid factor are now widely used as aids in the diagnosis of rheumatoid arthritis. The tests are either carried out in the test tube, or more recently as slide tests, the latter having the advantage of speed and simplicity.

Latex tests are very dependent on the properties of the latex suspension and $\gamma$ globulin employed. Coke (1959) found that a British latex preparation agglutinated spontaneously, and used the reaction as the basis of a latex agglutination inhibition test. $\mathrm{He}$ found that agglutination was not inhibited by the sera from patients with rheumatoid arthritis. Ziff (1957) demonstrated that an element in normal serum which inhibited agglutination of sensitized sheep cells was lost or blocked in sera from patients with rheumatoid arthritis. Although he obtained positive results in $98 \%$ of the cases the procedure was difficult and lengthy.

This paper describes a simple slide test in which agglutination of a latex suspension is inhibited by normal sera but not by most of the sera having a positive result with the Rose-Waaler test. Unlike tests dependent on the aggregation of latex particles by rheumatoid factor in the presence of added $\gamma$ globulin, the latex reagent used does not require additional $\gamma$ globulin. As in the latex fixation tube test described by Singer and Plotz (1958) this test utilizes the $\gamma$ globulin present in the patient's serum. The reagent may be prepared easily, and the sensitivity is not dependent on the degree of any denaturation or agglutination of added $\gamma$ globulin.

Factors influencing the test have been further

Received for publication 25 January 1962. investigated by chromatographic fractionation $0 \%$ the serum proteins on diethylaminoethylcellulose (Stanworth, 1960).

\section{MATERIALS AND METHODS}

BORATE-SALINE BUFFER AT $p \mathrm{H} 8.2$ Fifty $\mathrm{ml}$. of $0.1 \%$ boric acid and $5.9 \mathrm{ml}$. of $0.1 \mathrm{~N} \mathrm{NaOH}$ are made upste $100 \mathrm{ml}$. with water and the $p \mathrm{H}$ adjusted to 8.2 whep $0.85 \mathrm{~g}$. of $\mathrm{NaCl}$ is added to each $100 \mathrm{ml}$. of buffer.

BACTO $^{1}$ LATEX 0.81 SUSPENSION When diluted 1 in $1,00 \AA$ with water the light transmission measured in the Unicam S.P. 500 using $1 \mathrm{~cm}$. cells is in the range $62 \%$ to $67 \%$ and the optical density in the range $0 \cdot 21$ to 0.17 .

LATEX REAGENT One millilitre of the original Bacto Late suspension is diluted with $1 \mathrm{ml}$. of water and $3 \mathrm{ml}$. of the borate-saline buffer added to the $2 \mathrm{ml}$. of dilute latex suspension.

LATEX SLIDE TEST The test serum is heated at $56^{\circ} \mathrm{C}$. fo 30 minutes and $0.01 \mathrm{ml}$. added to $0.1 \mathrm{ml}$. latex reagent or a piece of glass (4 in. $\times 8$ in.) resting on black photo graphic paper. The serum and latex are thoroughly mixedf and the glass rocked by hand for two minutes. The tests are reported as strong positive when the latex particles. form large clumps within the first 30 seconds; as positive when clumps form within 60 seconds; and as weaklys positive when small but obvious clumps occur between one and two minutes. No change is seen in negative sera요 The piece of glass used enables 10 tests to be carried oufw together.

\section{RESULTS}

Comparisons were made with the sheep cell agglu-o tination (Rose-Waaler) test as described by Bal $\overline{\vec{D}}$

${ }^{1}$ Difco Laboratories, obtainable from Baird and Tatlock Ltd. 
(1950). In each case the Rose-Waaler test was carried out in parallel with the latex test. The results are recorded in Table I.

\section{TABLE I}

COMPARISON OF RESULTS IN 508 CASES

\begin{tabular}{llc} 
Rose-Waaler Test & Latex Test & No. of Cases \\
\hline Positive & Positive & $88(17 \%)$ \\
Positive & Negative & $9(2 \%)$ \\
Negative & Positive & $10(2 \%)$ \\
Negative & Negative & $401(79 \%)$
\end{tabular}

INVESTIGATION OF FACTORS INFLUENCING THE TEST EFFECT OF HEATING SERA AT $56^{\circ} \mathrm{C}$. Unless the sera were heated at $56^{\circ} \mathrm{C}$. in a water-bath before the slide test was done, agglutination occurred in normal sera. A heating time of 30 minutes was used routinely in order to keep conditions similar to those employed in the Rose-Waaler test; however, a heating time of 15 minutes was found to be satisfactory for the latex test.

EFFECT ON SERA OF DILUTION WITH BORATE BUFFER A normal serum diluted 1 in 5 with borate buffer gave a negative result. However, at a dilution of 1 in 10 a weakly positive result was obtained and at 1 in 20 the result was strongly positive.

A serum initially positive diluted with buffer in the same manner gave results unchanged throughout.

\section{PROPERTIES OF $\gamma$ GLOBULIN PREPARED FROM HUMAN SERA ON DIETHYLAMINOETHYLCELLULOSE}

Human $\gamma$ globulin was fractionated from other serum proteins using diethylaminoethylcellulose and phosphate buffer $p H \quad 7.5(0.01 \mathrm{M}$ containing $0.015 \mathrm{M} \mathrm{NaCl}$ ) at $4^{\circ} \mathrm{C}$. The method employed was that described by Stanworth (1960). The type 7S $\gamma$ globulin fraction was finally obtained in the phosphate buffer at a concentration of 100 to $200 \mathrm{mg}$./ $100 \mathrm{ml}$. This solution was used in the following experiments.

Electrophoresis of the $\gamma$ globulin fraction was carried out on paper using barbitone buffer at $p H$ 8.6. From Fig. 1 it can be seen that the prepared $\gamma$ globulin behaves electrophoretically in the same way as the $\gamma$ globulin in the normal control serum. When stained with bromophenol blue or nigrosine no other serum proteins could be seen.

When $0.01 \mathrm{ml} . \gamma$ globulin solution prepared from normal serum was added to $0 \cdot 1 \mathrm{ml}$. of latex reagent as described for the test, no agglutination occurred. However, when $\gamma$ globulin, prepared from a patient known to have a high Rose-Waaler titre, was added to the latex reagent the particles agglutinated in the same way as the unfractionated serum.

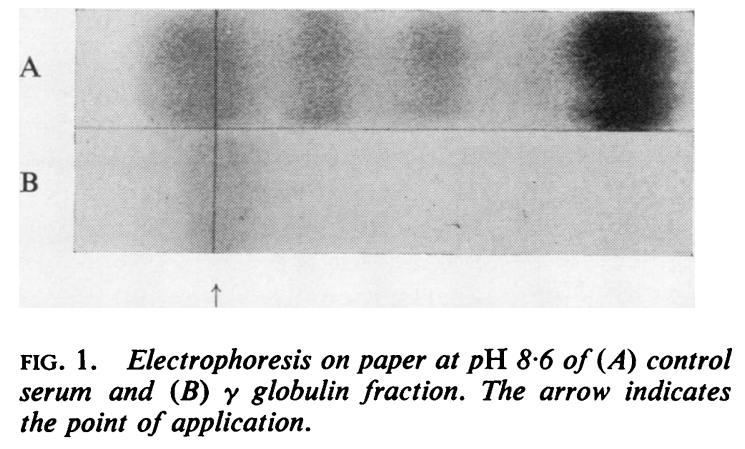

DISCUSSION

It will be seen from Table $I$ that there is overall agreement $(96 \%)$ between the Rose-Waaler test and the latex slide test. Out of the 97 cases with a positive Rose-Waaler test there were nine false negative latex tests $(9 \%)$. But in seven of these cases the Rose-Waaler titre was not more than 1 in 32, a result of doubtful clinical significance. As the RoseWaaler test was always set up in serial dilution, the occasional borderline case was more easily interpreted by this test. In 10 cases out of $411(2 \%)$ the latex test was positive and the Rose-Waaler test negative. It has been shown by Hammack and Holley (1961) that the Rose-Waaler test is slightly more specific and is less likely to be affected by conditions giving rise to grossly raised total $\gamma$ globulin levels. The work of Heller, Jacobson, Kolodny, and Kammerer (1954) indicates that fraction II and sensitized red cell tests are not indicating identical factors. However, the tests parallel one another in the majority of cases.

Agglutination occurred with normal sera unless the sera were heated at $56^{\circ} \mathrm{C}$. before the test was done. The reaction appeared to be dependent on the serum protein concentration being within a selected range. The ability of normal sera to inhibit agglutination was lost at a dilution greater than 1 in 10. Payne (1961) found that when bovine $\gamma$ globulin was added to a latex suspension the particles agglutinated at certain concentrations of $\gamma$ globulin but not at others. It may be that a similar phenomenon takes place when serum is diluted.

In earlier experiments it was thought that it would be necessary to prepare a latex $\gamma$ globulin reagent for this test, and a rapid diethylaminoethylcellulose method was used as a convenient method for preparing a suitable $\gamma$ globulin fraction. The results obtained when this fraction was added to the latex particles would suggest that the factors in the serum with the high Rose-Waaler titre were also present in the type $7 \mathrm{~S} \gamma$ globulin prepared from it. Rheumatoid 
factor is a macroglobulin which would not be expected to appear in this fraction, if completely pure. Stanworth (1960) considered slight loss of purity of the type 7S $\gamma$ globulin occurred if overnight dialysis before fractionation on diethylaminoethylcellulose was omitted. As this was not carried out it is possible that sufficient rheumatoid factor was included in the preparation to interact with the type 7S $\gamma$ globulin, causing agglutination of the particles.

The advantages that favour the use of the latex reagent described are relatively low cost of materials (less than 10s. per 100 tests), ease of preparation, and a sensitivity not dependent on the degree of any denaturation or agglutination of the added $\gamma$ globulin. For example, it was found that if small changes in $p \mathrm{H}$ of the diethylaminoethyl cellulose mixture occurred during the fractionation, a $\gamma$ globulin was prepared which caused spontaneous agglutination.
As an additional check on the method a control series was carried out with another hospital whereo the Hyland 'R.A. test' was in routine use. There was $=$ : complete agreement in 38 cases, of which six weres positive.

We should like to thank Dr. A. F. Mohun of the Whittington Hospital for his help in sending us sera for a control series, and Mr. A. W. Howes for his collabora-ñ tion in the Rose-Waaler tests.

\section{REFERENCES}

Ball, J. (1950). Lancet, 2, 520.

Coke, H. (1959). Ann. rheum. Dis., 18, 301.

Hammack, W. J., and Holley, H. L. (1961). J. Lab. clin. Med., 58, 366. $\rightarrow$ Heller, G., Jacobson, A. S., Kolodny, M. H., and Kammerer, W. H. G (1954). J. Immunol., 72, 66.

Payne, R. B. (1961). J. clin. Path., 14, 309.

Singer, J. M., and Plotz, C. M. (1958). Arthritis and Rheumatism, 1 N 142.

Stanworth, D. R. (1960). Nature (Lond.), 188, 156.

Ziff, M. (1957). J. chron. Dis., 5, 644. 